\title{
GLOBAL IMPACT AND REGIONAL DIMENSIONS OF SERVICES MARKET DEVELOPMENT IN UKRAINE
}

\author{
Kateryna Brenzovych ${ }^{1}$, Myroslava Tsalan²
}

\begin{abstract}
In the context of decentralization processes in Ukraine, the development of perspective segments of the service sector that can be oriented at an external domestic or foreign consumer, should be in the focus of attention of local authorities and self-government bodies. For this reason, the purpose of the paper is to explore the theoretical foundations and practical realities of developing regional service markets in Ukraine, to study the influence of national and global factors on the tertiary sector development. Methodology. The study is conducted with the application of general scientific and specific methods of economic research. In particular, the methods of analysis and synthesis were used in assessing the structure of the services market according to statistical observations. The classification method is applied in the author's vision of division of services. The use of induction and extrapolation methods made it possible to distinguish the general features of services, based on certain occasions and market indicators and to extend them to a general structure. Results show the current state and development specifics of the services market of Ukraine in the regional dimension and the prospects of export specialization of its regions and trade in services in the context of Ukraine's participation in the WTO and association with the EU. Particular attention is paid to the study of the development of services market at the regional level, since the functioning of the services market has a clearly identified regional orientation, which causes significant differences in the development of entrepreneurship in the service sector at both the regions of the global economy, country and the local administrative and territorial entities. Some types of services are "tied" to the territory (for example, tourist locations), others have to be close to potential consumers (utility, personal, household services). The financial services sector is excluded from the subject of the study, which is explained by higher globalization of this type of services and much lower relation to regional development. Practical implications. The study of services sector development will be useful for local and national authorities while taking measures on local development programs. Value/originality. The study takes into account both local and global factors influencing the services market development, which is especially valuable in the context of Ukraine's aspirations of integration to the European Union.
\end{abstract}

Key words: service, services sector, development, foreign trade, export, import.

JEL Classification: F14, R12, R50

\section{Introduction}

It is widely recognized that in current time, services sector is one of the major drivers of economic growth in all countries, regardless of the level of development of their productive forces. However, while in developed countries the basis of economic development is now formed by the highly productive services in the field of IT and business services, in the countries under transition to the market economy and in underdeveloped countries the main contribution to the gross product is made by transport and communication services, tourism. At the same time, the analysis of the world experience shows that the services sector is an extremely dynamic part of the economy, which plays an important role in solving a range of problems, including improving the efficiency of munufacturing and overcoming unemployment, ehhancing the quality of life.

The residual approach in the study of service sector in Ukraine in the past as in other post-socialist countries, has led to an underestimation of its role in the structure of the national economy, as a result - to the slow and

\footnotetext{
Corresponding author:

${ }^{1}$ Uzhgorod National University, Ukraine.

E-mail: kateryna.brenzovych@uzhnu.edu.ua

ORCID: https://orcid.org/0000-0002-1935-3581

${ }^{2}$ Uzhgorod National University, Ukraine.

E-mail: myroslava.tsalan@uzhnu.edu.ua

ORCID: https://orcid.org/0000-0003-1878-1346
} 
disproportionate development of this sector in the context of market economy restructuring. Thus, in Soviet times, services sector was considered 'nonproductive' comparatively with manufacturing. At the same time, unavoidable reforming of the service sector in the context of restructuring property relations has led to the development of new forms of activity based on the principles of private property, competition and free pricing.

\section{Results}

Regional services markets, as well as commodity markets, are parts of a single integrated complex of the national market, also being a system of local relations regarding the production and consumption of services, which are indispensable components of the economic functioning of the region, and therefore require a comprehensive management approach. The services market, as compared to the goods market, is characterized by a higher level of localization, which arises primarily from the feature of the service - the continuity of the process of its production and sale. The territorial proximity of manufacturers and consumers of services enables more close reflection of the needs for services and taking into account the product requirements that are addressed by local consumers (there is a kind of "involvement" of customers in the process of development and improvement of services production). The higher the degree of customer involvement in the processes of service delivery, the greater importance is attached to the study of customer interests in the activities of enterprises in the market the greater the degree of integration of the territorial complex of services in the system of regional and national economy.

The processes at the services market in the region are determined by the influence of factors at three levels regional, national and global.

Local (regional) factors, such as resource background for the development of the service sector, real opportunities for enterprises to create the supply of such services, demand for services in the region (consumer needs), the role of local authorities in facilitating the development of the regional market, in our view, are of extreme importance. Here is an example of the development of tourism enterprises related to the service sector around a particular tourist attraction in the region. Resources (availability of tourist attractions) form the basis for offering tourist, hotel and restaurant services and amenities around such an attraction. If the existing entrepreneurial potential is able to accumulate its capabilities, and able to show elasticity if necessary - to change the specialization by responding to the need (in this case - the need for recreation), then with the assistance (or at least not impediment) from the side of local authorities, the result can be to create a range of enterprises at a certain territory, which will provide tourist and recreational services in accordance with the emerging demand. National factors include legislative background, the macroeconomic situation in the country, the governmental support for the development of the regions. The macroeconomic situation describes the general conditions for the functioning of services markets - for example, the presence of solvent demand for services which is highly dependent from the income level. National legislation in the sphere of functioning of a service company both creates general conditions for work and implementation of the principle of freedom of enterprise, and can provide special favorable conditions for business development in particular areas by easing tax pressure. Global factors shape the general trends in the service sector, promote the diffusion of innovative technologies and best management practices in service delivery, create favorable or discriminatory conditions for international trade in services, including restrictions or ease in the entry of local service providers into the international market. Table 1 lists the factors influencing the development of regional services market.

Thus, the formation and development of the services market in the region is influenced by the intra-regional needs of certain services from the side of the population and enterprises. After all, as some authors point out, the industries that are intended to serve the population of the region are more oriented towards meeting specific regional needs. They fulfill the common economic needs as regional needs, which are part of the national economic needs, as well as the regional economy is a structural part of the national economy of Ukraine (Yemets, Lendyel, 1992).

Thus, the sphere of services of the region is intended, firstly, to meet the needs of the population and enterprises of the region, and, secondly, to create and implement services for external consumers outside the region - to citizens of Ukraine and enterprises from other regions, and to foreign consumers. At the same time, the status of the border area and close proximity to the state border should create significant advantages for enterprises willing to meet a foreign buyer. On the other hand, such a territorial approximation implies an increased reverse effect of cross-border trade in services on the emergence of local markets.

For a detailed analysis of the status, trends and prospects of the services market development in Ukaine in regional context, it is necessary to define the institutional and specific structure of the market.

Considering the general approaches to the allocation of services sector in the structure of the national economy (Danylyshyn, 2005), (Chernysh, 2005), (Fedoron'ko \& Kovalchuk, 2017), their consistency with the existing rules of statistical accounting and the 
Table 1

Factors, influencing the development of regional services markets

\begin{tabular}{|l|l|l|}
\hline \multicolumn{1}{|c|}{ Global } & \multicolumn{1}{|c|}{ National } & \multicolumn{1}{c|}{ Local (regional) } \\
\hline $\begin{array}{l}\text { scientific and technological progress, and structural } \\
\text { and technological changes in production }\end{array}$ & $\begin{array}{l}\text { general macroeconomic situation in } \\
\text { the country }\end{array}$ & $\begin{array}{l}\text { needs for services from local and external } \\
\text { customers }\end{array}$ \\
\hline $\begin{array}{l}\text { increasing living standards and growing demand for } \\
\text { services }\end{array}$ & $\begin{array}{l}\text { national legislation in the field of } \\
\text { entrepreneurship }\end{array}$ & $\begin{array}{l}\text { resource potential of the region in terms of } \\
\text { development of specific sectors of services }\end{array}$ \\
\hline liberalization of international trade in services & $\begin{array}{l}\text { level of involvement of the country } \\
\text { in international trade and integration } \\
\text { processes }\end{array}$ & $\begin{array}{l}\text { competitiveness of regional enterprises and } \\
\text { elasticity of production structure }\end{array}$ \\
\cline { 2 - 3 } international economic integration & $\begin{array}{l}\text { a vision of the development of services market } \\
\text { by local authorities }\end{array}$ \\
\hline
\end{tabular}

Source: built by the authors

system of national accounts, it is possible to define the regional services market as a system that integrated elements (institutional units providivng services) which are referred by the methodology of statistics to certain kinds of activity and provide services that can be considered as marketable by their economic characteristics. The division of services by economic characteristics and institutional units is based on the definition of market and non-market output by the System of National Accounts (SNA) and is widely used in scientific research as the main criterion for the division of services.

Institutional units that provide services under the SNA are: non-financial corporations, financial corporations, public sector, household sector and non-profit sector serving households (United Nations Statistics Division, 2012). It should be added that the great role of service providers at the regional level is played by individual entrepreneurs, but the statistical account of the volume of services provided by them is extremely imperfect, which narrows the possibilities of an adequate assessment of their role at the market.

Since 2002, the Statistical Service of Ukraine is conducting a statistical survey of the non-financial services enterprises activities, which covers the activities of business entities identified as service businesses (by their main activity). Such surveys are conducted in accordance with the National Classification of Kinds of Economic Activity, in accordance with the System of National Accounts and with the requirements of the United Nations. According to the methodology of service statistics, non-financial services by types of economic activity are classified into Sections:

Section G (maintenance and repair of motor vehicles, motorcycles; repair of household goods and personal items), Section $\mathrm{H}$ (operation of hotels and other temporary accommodation), Section I (transport and communication activities), Section K (Real estate activities, renting, engineering and business services), Section M (education), Section N (Health and social assistance), Section $\mathrm{O}$ (Provision of public utilities and individual services; cultural and sports activities) (State Statistics Service of Ukraine, 2011).
The study of regional service markets development requires introduction of an additional criterion of classification - the direction (level) of provision on the basis of consumer's residence. In the processes of regionalization and globalization of the economy, the problem of identifying those sectors of the regional economy that form competitive positions of the territory, including in the world market, is of great importance. Thus, in the direction of service delivery, it is advisable to divide them into those that provide services mostly for local needs (from the population, businesses), and those that are considered in the long term as a product of industries specializing in the region and focused on external consumers.

Thus, by all defined criteria, the regional services market covers the activities of economic entities (legal entities, their branches and separate subdivisions and natural persons - entrepreneurs of the region), providing non-financial services on a market basis, at economically significant price for the aim of getting profit. The main indicators for assessing the development of regional service markets are: the total volume of services produced and rendered, the share of regions in national production of services, the contribution of the service sector to the creation of gross regional product (in \%), the number of enterprises active in the service sector and employment in such enterprises, as well as the level of integration of regional services markets into the global one, which is estimated by the overall indicators of foreign trade performance (exports, imports, trade balance, foreign trade ratio).

The total value of the services provided in 2018 was more than 702 UAH billion (State Statistics Service of Ukraine, 2019). However, this sum is not including the data of enterprises, which are not covered by a regional statistics and are submitting statistical reports without distribution by region. The additional amount of such services is more than $70 \mathrm{UAH}$ billion. The study of regional shares in the total production of services shows that the Kyiv city, Odesa, Dnipropetrovsk and Kharkiv regions are the main producers of services in Ukraine. These regions however are the most populated and developed in the sense of number of 
active enterprises that explains the high demand for services. The less populated regions - Khmelnytsky, Chernivtsy, Sumy, and the unoccupied territory of Luhansk regions have less than $1 \%$ share in the total productions of services across the national economy. Lviv region is a unique for having a share of almost $6 \%$ that is almost equal to the share of Kyiv region (while Lviv region is having relatively less population and high share of people living in rural area, that usually causes low demand for services). Most services in Ukraine are consumed by the enterprises (about $65 \%)$. However all the regions can be divided into three groups: those, in which services predominantly are consumed by the enterprises, those where services are provided mostly to individuals and those where the share of legal entities and individual consumers is about equal. Enterprises in Ukraine are consuming transport services, warehousing and support activity in the sphere of transport, services in the sphere of law, accounting and auditiong, architecture and engineering, technical testing and research, activity of the head-offices, management consultancy, R\&D. Individual consumers are mostly buying temporary accommodation and catering, education, telecommunications (electric communications), healthcare, art, sport, entertainments and recreation services. Table 2 shows the breakdown of regions according to the share of enterprises and individuals in the total consumption of services.

As the table 2 shows, in most (17) regions enterprises prevail in the share of consumed services, in others (6) businesses and individual consumers have roughly the same numbers. Only in the unoccupied part of the Luhansk region and in the Chernivtsi region services are mainly consumed by the population. Kyiv, Kirovohrad and Dnipropetrovsk regions have the largest share of enterprises in the structure of consumption of services, which is explained by high entrepreneurial activity in the regions itself. This division, in our opinion, does not significantly depend on the geographical location, but rather on the level of development of business in the region. It should also be borne in mind that a significant amount of services in Ukraine is provided by self-employed individuals. However, statistical records in terms of services provided by them are not maintained, and therefore cannot be taken into account.

The number of jobs created in services sector is an important aspect of the services market development and way of assessing the contribution of the tertiary sector to regional development. In general, agriculture in Ukraine employs about $18 \%$ of workers, industry $15 \%$, construction $-4 \%$, the rest $63 \%$ of jobs refer to services sector, including financial services and public administration. This indicator is close to employment data of developed countries, but the leading role of education and health services, which remain labor intensive even in developed countries due to the specific nature of their delivery, must be taken into account. In all regions of Ukraine, the largest number of population is employed in education and medicine - more than 2.4 million people (State Statistics Service of Ukraine, 2018). Most educational and medical institutions are budgetary institutions and provide non-market services, and therefore cannot be calculated in our study. The analysis of the other services sectors in terms of employment shows the following:

1) in spite of the expectation that the regions in which the largest number of employees are involved in the

Table 2

\section{Regions of Ukraine according to the share of enterprises and individuals in consumption of services}

\begin{tabular}{|c|c|c|}
\hline $\begin{array}{l}\text { Regions, where services are predominantly } \\
\text { consumed by enterprises (17) }\end{array}$ & $\begin{array}{l}\text { Regions, where services are predominantly } \\
\text { consumed by individuals }(2)\end{array}$ & $\begin{array}{l}\text { Regions with almost equal share } \\
\text { of enterprises and individuals } \\
\text { in consumption of services }(6)\end{array}$ \\
\hline $\begin{array}{c}\text { Volyn } \\
\text { Dnipropetrovsk } \\
\text { Donetsk } \\
\text { Zhytomyr } \\
\text { Zakarpattya } \\
\text { Zaporizhzhya } \\
\text { Kyiv } \\
\text { Kirovohrad } \\
\text { Lviv } \\
\text { Mikolayiv } \\
\text { Odesa } \\
\text { Poltava } \\
\text { Rivne } \\
\text { Kharkiv } \\
\text { Khmelnytskiy } \\
\text { Cherkasy } \\
\text { city of Kyiv } \\
\end{array}$ & $\begin{array}{l}\text { Chernivtsi } \\
\text { Luhansk }\end{array}$ & $\begin{array}{c}\text { Vinnytsya } \\
\text { Ivano-Frankivsk } \\
\text { Sumy } \\
\text { Ternopil } \\
\text { Kherson } \\
\text { Chernihiv }\end{array}$ \\
\hline
\end{tabular}

Source: built by the authors based of data of (State Statistics Service of Ukraine, 2019) 
service sector are the most populated regions, the latter do not have high employment rates in the enterprises providing market services, since the largest share of population is still employed in the "budget" part of services sector - education and medicine;

2) in highly urbanized regions (Dnipropetrovsk, Kyiv, Kharkiv regions) the role of employment in the transport sector is especially significant; a high number of jobs is created in close-to-border Lviv region and the coastal region of Odessa;

3) Lviv oblast is unique in terms of employment development in the catering sector and accommodation, which exceeds all regions of Ukraine except Kyiv by the number of employed in this field. This is explained by the tourist attractiveness of the region and the high level of development of tourist and recreational infrastructure;

4) Kyiv is the undisputed leader in terms of employment in information and telecommunications sector, with more than 90,000 jobs (for comparison, in Kharkiv region, where population is 200,000 more than the population of Kyiv city, only 25,000 people are working in the field of information and telecommunications).

After Ukraine's participation in the WTO, particularly in the General Agreement on Trade in Services, the competitive environment in the national market has improved significantly, and consumers have accordingly benefited from the consumption of a larger range and quality of service products. Ukraine has made commitments in the main sectors of GATS, including business services, communications, distribution, education and environmental services, finance (insurance and banking), and healthcare. This list also includes social services, tourism and travel services, recreation, culture and sports, transportation services, beauty services (hairdressing, spa and massage). Ukraine has pledged not to discriminate against foreign companies in the vast majority of service sectors, except in such areas as security and investigation services, audiovisual services, space transport services, towing and unloading services by sea and rail. Restrictions were introduced in a number of sectors (inland waterway and rail transport, land operations), as well as on foreign capital and the presence of foreign persons. Ukraine is actively applying WTO mechanisms to protect national interests, while liberalizing access rules to the national market, which ultimately leads to an increase in exports and imports of services.

The EU-Ukraine Association has also had a positive impact on Ukraine's foreign trade in services with the EU member states. The overall indicators of export and import have increased, the positive balance of trade in services is maintained and the share of the innovative, scientific and technical and information services in the structure of Ukrainian exports is constantly growing. In 2019, Ukrainian enterprises sold export services for more than US \$ 15,5 billion, that is nearly
2,5 times more than the volume of services imported into Ukraine (US \$ 6,4 billion) (State Statistical Service of Ukraine, 2020).

Data available on the quantity of active enterprises show that in total, almost 7,000 Ukrainian enterprises exported services in 2018. Most of the enterprises were registered in Kyiv city (2,823 units) and in Kyiv region (300), in the coastal Odessa (812) and western regions bordering the EU - Transcarpathian region (194) and Lviv (576) (State Statistical Service of Ukraine, 2019). Exporters from Mykolaiv, Chernivtsi, Transcarpathian, Ternopil and Lviv regions were the most effective in their activity, as the export coverage ratio was 7.1 and higher (with an average ratio of 2,4 in Ukraine). Only 4 regions have had negative foreign trade in services coverage ratio (much less than 1) - Donetsk, Dnipropetrovsk, Volyn and Vinnytsya regions, and three regions were close to 1.0 ratio when export and imports were almost equal. Data on the Autonomous Republic of Crimea and the occupied territories of Donetsk and Luhansk regions are not taken into account in the calculation of indicators.

Almost one-third of all exports of services from Ukraine refers to the city of Kyiv (30.5\% in 2018 and $26,8 \%$ in 2019), and the largest amounts of services related to national exports were coming from Lviv, Mykolaiv, Kharkiv, Kyiv and Transcarpathia regions. Kyiv city imports almost half of the services from abroad (50,5\% in 2019), followed by Dnipropetrovsk, Kyiv and Odesa regions (State Statistical Service of Ukraine, 2020).

Liberalization of trade in services generally and improvement of trading conditions with the EU countries in particular had the most obvious impact on the indicators of regions of Ukraine, which are bordering with the Union. For example, 10 years ago (in 2010), the Transcarpathian region ranked only 15th in Ukraine in terms of export of services, while today it is at the 7 th place according to this indicator. Considering the state and dynamics of foreign economic activity of enterprises, given by the official statistics service, we can state:

- most regions of Ukraine show positive dynamics of foreign trade in services;

- by the period of 2015-2019, the rapid decline in trade in services caused by military conflict in the East of Ukraine was compensated due to the increase in exports from Kyiv and Kyiv region, southern Odessa and Mykolaiv, and western Lviv and Transcarpathian regions;

- the structure of foreign trade in services is being improved in all regions - the role of traditional services (transport and communication) is decreasing, while the share of the modern services in the field of telecommunications, computer and information is increasing. At the same time, the import volumes of leasing operations, tourist trips abroad and the 
volume of air transport are also increasing (which is a clear consequence of the liberalization of trade with the EU and the introduction of a visa-free regime with the EU).

\section{Conslusions}

The socio-economic nature of the services market is seen in its economic and specific functions. The services market acts as a set of relations in production and consumption of services, based on the processes of their sale and purchase at a price, which is set by the forces of supply and demand under the indirect influence of the non-market segment on the environment of these relations.

The main two functions of the services market are the creation of a comfortable and favorable living environment for the population, and the provision of conditions for the development of efficient manufacturing and other sectors of the national economy. The study of regional peculiarities of the services market development confirms, that the dynamics of processes in the market, the structure of consumption of services is determined first of all by the needs of potential consumers. Some regions, such as industrial Kharkiv and Dnipropetrovsk, have regional service markets focused on providing business services (services provided to enterprises), and at the same time have a developed transport services sector due to the high degree of urbanization. Kyiv region and Kyiv city concentrate the largest number of enterprises and employees in the service sector and are the leaders of the information and telecommunication services market. The bordering regions of Lviv and Transcarpathia make a significant contribution to foreign trade in services of Ukraine, mainly with the European Union.

The Ukrainian tertiary sector is developing under the influence of local, national and global factors. Over the past years, Ukraine's economy has experienced at least two external shocks - the global economic crisis and the Russian military invasion. However, significant reductions in the volume of service provision due to the loss of parts of Donetsk and Luhansk regions were successfully offset by the revitalization of enterprises in other regions. The positive impact of Ukraine's accession to the WTO was reflected in the growth of foreign trade in services, improvement of the structure of exports due to increasing the share of modern research, information and business services.

Currently, Ukraine's economy is overcoming economic crisis caused by the COVID-19 pandemic, which will unevitably cause great losses in regional and foreign trade in services. Thus, the influence of pandemic on trade in services will be the topic of the further studies.

\section{References:}

Chernysh, O. (2005). Services Market: Mechanisms of State Regulations in Transitional Economy. Donetsk.

Danylyshyn, B. (2005). Services Sector and Services Market in the Context of Social Modifications of Society. Kyiv: RVPS of NAS Ukraine.

Fedoron'ko, N., \& Kovalchuk, N. (2017). Current Situation at Services Market of Ukraine. Young Researcher, 3(43), 871-874.

State Statistics Service of Ukraine (2011). Classification of Kinds of Economic Activities-2010. Available at: http://kved.ukrstat.gov.ua/KVED2010/kv10_i.html

State Statistics Service of Ukraine (2019). Regions of Ukraine, 2020 (in two parts). Kyiv.

State Statistical Service of Ukraine (2020). Ukraine's Foreign Trade in 2019 (Statistical yearbook). Kyiv.

United Nations Statistics Division (2012). System of National Accounts-2008. Available at: https://unstats.un.org/ unsd/nationalaccount/docs/SNA2008Russian.pdf

Yemets, H., \& Lendyel, M. (1992). Regional Approach to Managing Economic Processes. Kyiv. 